\title{
Campylobacter enterocolitis: the importance of macroscopic and microscopic examination of stool
}

\author{
Yasuhiro Kano
}

Department of General Internal Medicine, Tokyo Metropolitan Tama Medical Center, Fuchu, Tokyo, Japan

\section{Correspondence to} Dr Yasuhiro Kano: yasuhiro.kano.21@gmail.com

Accepted 15 October 2021

\section{DESCRIPTION}

A previously healthy, 29-year-old, male patient presented with a 3 -day history of a $39-40^{\circ} \mathrm{C}$ fever and more than 10 daily episodes of diarrhoea. $\mathrm{He}$ denied abdominal pain, nausea, haematochezia and chills. He had no history of recent travel or contact with animals or sick individuals. On presentation, he was haemodynamically stable. His body temperature decreased to $37.0^{\circ} \mathrm{C}$ with loxoprofen use, and his other vital signs were normal. Abdominal examination revealed normal bowel sounds and no tenderness. The rest of the physical examination was unremarkable. Initial basic lab work, including a complete blood count and basic metabolic panel, was normal except for an elevated $\mathrm{C}$ reactive protein level of 18.29 (normal <0.14) $\mathrm{mg} / \mathrm{dL}$. Further questioning revealed that he had eaten food containing chicken every day prior to the presentation, which raised suspicion of Campylobacter enterocolitis, and a stool culture was ordered. Initially, he described his bowel movements as watery diarrhoea; however, the attending physician described the stools as having a mucoid appearance (figure 1). A subsequent, microscopic stool examination using a Gram stain revealed Gram-negative spiral rods strongly suggestive of Campylobacter sp (figure 2). Campylobacter enterocolitis was soon diagnosed, and oral azithromycin $500 \mathrm{mg}$ per day was prescribed for 3 days, leading to a complete resolution of his symptoms. Three days after his first visit, the stool culture grew Campylobacter jejuni. The patient was informed of the risk of Guillain-Barré syndrome development.

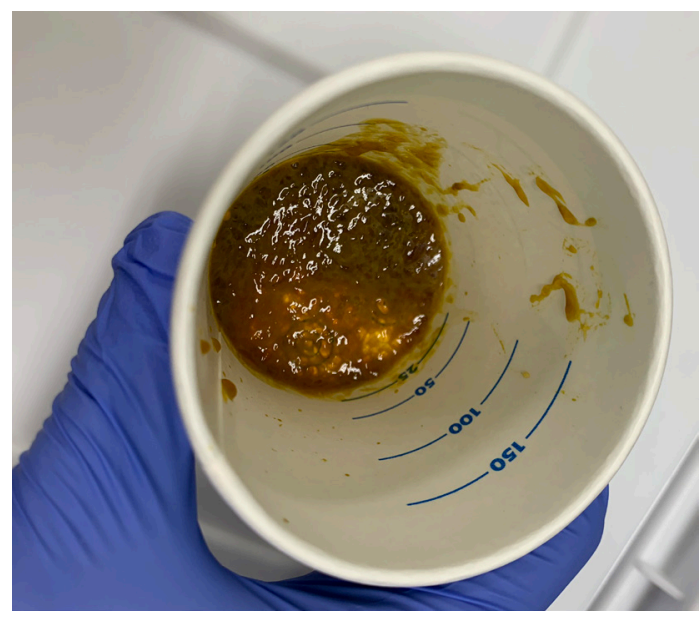

Figure 1 Stool samples showing faeces with a mucoid or gelatinous appearance.

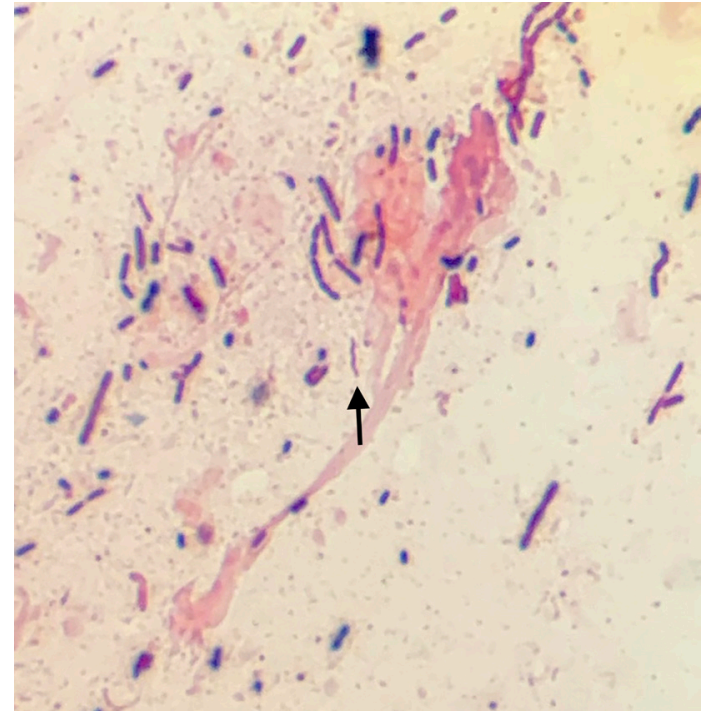

Figure 2 Gram stain of stool showing Campylobacter jejuni appearing as small, Gram-negative, curved rods (arrow).

The present case highlights two clinical lessons; first, the importance of physicians' examining patients' stool samples macroscopically; and, second, the usefulness of Gram staining stool samples for rapid microscopic examination when managing acute diarrhoea.

The characteristics of stool, such as whether it is watery, bloody, mucoid, purulent or bilious, are important for classifying the aetiology of acute diarrhoea as non-inflammatory (mostly due to a viral infection) or inflammatory (mostly due to an invasive or toxin-producing bacterial infection). ${ }^{1}$ However, patients' description of their stool is often inaccurate and misleading as in the present case. While stool samples are often sent directly to a laboratory for testing, a visual inspection by the physician may reduce the risk of misdiagnosis and help clarify the indications for further tests, including a stool culture.

Gram staining of faecal samples is an inexpensive, rapid and highly accurate method of diagnosing Campylobacter enterocolitis. Its specificity for detecting Campylobacter sp infections is as high as $99.4 \%-99.7 \%$ while its sensitivity varies from $46 \%$ to $89 \%$ depending on the examiner's skill. ${ }^{23}$ Thanks to the high specificity of the Gram stain test, the finding of Gramnegative spiral rods by microscopy coupled with the absence of bloody stools on macroscopic inspection, render other diagnoses less probable and can help prevent the unnecessary 


\section{Patient's perspective}

I was very nervous about my high fever and diarrhoea because of the possibility of having COVID-19. The fever felt a bit different from the influenza, but I was relieved to get a quick diagnosis of Campylobacter enterocolitis in the emergent department.

\section{Learning points}

- Macroscopic features of stool are important in assessing the aetiology of acute diarrhoea.

- Practitioners should inspect stool samples because patients' descriptions are often inaccurate and misleading.

- Gram staining of faecal samples is an inexpensive, rapid and highly accurate method of diagnosing Campylobacter infections.

prescription of antimicrobial agents based on misdiagnosis. Nonetheless, the utility of Gram staining of stool samples depends on the regional epidemiology of enteritis. An estimate of pretest probability, which is based on a combination of regional epidemiology and individual history taking, including food consumption and recent travel, is important.

Acknowledgements We thank James R Valera for his assistance with editing the manuscript.

Contributors YK contributed to patient care, planning, conduct and writing up the work.

Funding The authors have not declared a specific grant for this research from any funding agency in the public, commercial or not-for-profit sectors.

Competing interests None declared.

Patient consent for publication Consent obtained directly from patient(s)

Provenance and peer review Not commissioned; externally peer reviewed.

\section{ORCID iD}

Yasuhiro Kano http://orcid.org/0000-0003-1210-2859

\section{REFERENCES}

1 Barr W, Smith A. Acute diarrhea. Am Fam Physician 2014;89:180-9.

2 Wang H, Murdoch DR. Detection of Campylobacter species in faecal samples by direct gram stain microscopy. Pathology 2004;36:343-4.

3 Ho DD, Ault MJ, Ault MA, et al. Campylobacter enteritis: early diagnosis with gram's stain. Arch Intern Med 1982;142:1858-60.

Copyright 2021 BMJ Publishing Group. All rights reserved. For permission to reuse any of this content visit

https://www.bmj.com/company/products-services/rights-and-licensing/permissions/

BMJ Case Report Fellows may re-use this article for personal use and teaching without any further permission.

Become a Fellow of BMJ Case Reports today and you can:

- Submit as many cases as you like

- Enjoy fast sympathetic peer review and rapid publication of accepted articles

- Access all the published articles

Re-use any of the published material for personal use and teaching without further permission

\section{Customer Service}

If you have any further queries about your subscription, please contact our customer services team on +44 (0) 2071111105 or via email at support@bmj.com.

Visit casereports.bmj.com for more articles like this and to become a Fellow 